\section{Analisis Yuridis Pembatalan Hak Untuk Melakukan Perkawinan Antara Sesama Pekerja Dalam Satu Perusahaan (Studi Putusan Mahkamah Konstitusi Nomor 13/PUU-XV/2017)}

Oleh :

\author{
Olivia Sitanggang ${ }^{1}$ \\ sitanggangolivia@gmail.com \\ Dr. Dedi Harianto, S.H., M.Hum, \\ Dr. Mustamam, M.
}

\begin{abstract}
Currently, there are several companies that make regulations that require the workers to resign or even be willing to be laid off if they decide to marry another worker in the company. Some of the reasons are preventing personal conflict, subjectivity, corruption, collusion and nepotism. The formulation of the problem in this research is what is the background of the provisions regarding the prohibition of marriage between fellow workers in one company, how is the analysis of the judges legal considerations in the decision Number 13 / PUU-XV / 2017, what is the impact of the Constitutional Court decision on the inclusion of clauses prohibiting intermarriage between workers.
\end{abstract}

The results showed that the background of the provisions concerning the prohibition of marriage between fellow workers in one company is to maintain a professional attitude of workers when carrying out their work in order to maintain the company's existence in the world of business competition. Another reason is that it refers to Article 153 paragraph (1) letter $f$ of Law Number 13 of 2003 so that this provision is used as a reason for employers to prohibit marital ties for fellow workers in their company. The legal consideration of the judge in decision Number 13 / PUU-XV / 2017 is clear that Article 153 paragraph (1) letter $f$ of the Labour Laws is no longer valid, because the phrase unless it has been regulated in a work agreement, company regulation, or collective working agreement is contrary to the Constitution 1945 and has no binding legal force. The impact of the Constitutional Court's decision on the inclusion of a clause on the prohibition of marriage is that employers cannot state the reasons for dismissal of workers who have marital ties to other workers in the same office in the employment agreements, company regulations or collective working agreements, so that if the entrepreneur includes it, it is considered to have violated the decision of the Constitutional Court.

\footnotetext{
Keywords: Cancellation of the Rights, Marriage, Workers, One Company.
}

\section{Abstrak}

Saat ini ada beberapa perusahaan yang membuat aturan yang mengharuskan pekerjanya mengundurkan diri atau bahkan bersedia di-PHK apabila ia memutuskan menikah dengan pekerja lain di perusahaan tersebut. Alasannya, antara lain, mencegah konflik pribadi, subyektivitas, korupsi, kolusi, dan nepotisme. Rumusan masalah dalam penelitian ini adalah bagaimana hal yang melatar belakangi ketentuan tentang larangan perkawinan sesama buruh atau pekerja pada satu perusahaan, bagaimanakah analisis pertimbangan hukum hakim dalam putusanNomor 13/PUU-XV/2017, bagaimana dampak adanya putusan Mahkamah Konstitusi terhadap pencantuman klausul larangan perkawinan antar pekerja.

Hasil penelitian menunjukkan bahwa yang melatar belakangi ketentuan tentang larangan perkawinan sesama buruh atau pekerja pada satu perusahaan adalah untuk menjaga sikap profesional dari pekerja ketika melaksanakan pekerjannya demi menjaga eksistensi perusahaan dalam dunia persaingan bisnis. Sebab lainnya adalah mengacu kepada Pasal 153 ayat (1) huruf $f$ Undang-Undang Nomor 13 Tahun 2003 sehingga ketentuan tersebut digunakan sebagai sebab bagi pengusaha melarang adanya ikatan perkawinan bagi sesama pekerja dalam perusahaannya. Pertimbangan hukum hakim dalam putusan Nomor 13/PUU-XV/2017 adalah jelas bahwa Pasal 153 ayat (1) huruf $f$ Undang Undang Ketenagakerjaan tidak berlaku lagi, karena frasa kecuali telah diatur dalam perjanjian kerja, peraturan perusahaan, atau perjanjian kerja bersama bertentangan dengan UUD Tahun 1945 dan tidak mempunyai kekuatan hukum mengikat. Dampak adanya putusan Mahkamah Konstitusi terhadap pencantuman klausul larangan perkawinan adalah pengusaha tidak dapat mencantumkan alasan adanya PHK terhadap pekerja yang memiliki ikatan perkawinan dengan pekerja lain pada satu kantor yang sama dalam perjanjian kerja, peraturan perusahaan maupun perjanjian kerja bersama, sehingga apabila pengusaha mencantumkan hal tersebut maka dianggap melanggar putusan Mahkamah Konstitusi.

Kata Kunci: Pembatalan Hak, Perkawinan, Pekerja, Satu Perusahaan.

${ }^{1}$ Alumni Magister Hukum UISU 
Media Komunikasi dan Informasi Hukum dan Masyarakat

\section{Pendahuluan}

\section{A. Latar Belakang}

Perkawinan merupakan suatu cara untuk menyalurkan kebutuhan biologis antara laki-laki dan wanita dan menghubungkannya sebagai suami isteri. Hal tersebut merupakan suatu ikatan yang paling kuat dalam hubungan pergaulan manusia. ${ }^{2}$ Pasal 1 Undang-undang Nomor 1 Tahun 1974 Tentang Perkawinan (selanjutnya disebut UU Perkawinan) bahwa yang dimaksud dengan perkawinan adalah ikatan lahir dan batin antara seorang pria dan wanita sebagai suami isteri dengan tujuan untuk membentuk keluarga (rumah tangga) yang bahagia dan kekal berdasarkan ketuhanan Yang Maha Esa. ${ }^{3}$

Perkawinan merupakan suatu hal yang penting dalam realita kehidupan manusia. Dengan adanya perkawinan rumah tangga dapat ditegakkan dan dibina sesuai dengan norma agama dan tata kehidupan dalam masyarakat. Dalam rumah tangga berkumpul dua insan yang berlainan jenis (suami isteri), mereka saling berhubungan agar mendapat keturunan sebagai penerus generasi. "Kuat lemahnya perkawinan sangat tergantung pada kehendak dan niat suami isteri yang melaksanakan perkawinan tersebut, oleh karena itu dalam suatu perkawinan diperlukan adanya cinta lahir bathin antara pasangan suami isteri. ${ }^{4}$

Tujuan dari perkawinan menurut UU Perkawinan adalah membentuk keluarga yang bahagia yang kekal abadi. Suami isteri harus saling lengkap-melengkapi antar satu sama lain, pengertian, saling membantu dapat

\footnotetext{
${ }^{2}$ Kamal Mukhtar, Asas-Asas Hukum Islam Tentang Perkawinan, Bulan Bintang, Jakarta, 2013, hal. 8.

${ }^{3}$ Soemiyati. Hukum Perkawinan Islam dan Undang-Undang Perkawinan. Liberti, Yogyakarta, 2012, hal. 43 .

${ }^{4}$ Abdul Manan, Aneka Masalah Hukum Materil dalam Praktek Peradilan Agama, Pustaka Bangsa, Jakarta, 2003, hal. 1
}

mengembangkan kepribadiannya untuk membantu dan mencapai kesejahteraan baik spritual maupun material. ${ }^{5}$

Perkawinan dalam Islam tidaklah sematasemata sebagai hubungan atau kontrak keperdataan biasa, akan tetapi ia mempunyai nilai ibadah. "Kompilasi Hukum Islam menegaskannya sebagai akad yang sangat kuat (mitsaqon gholiidan) dan untuk mentaati perintah Allah dan melaksanakannya merupakan ibadah (Pasal 2 Kompilasi Hukum Islam) ${ }^{6}$

Terkait perkawinan, saat ini beberapa perusahaan baik perusahaan pemerintah, maupun swasta, menetapkan suatu klausul yang membatasi hak untuk melangsungkan perkawinan antara sesama pekerja yang bekerja dalam perusahaan tersebut.

Salah satu peraturan perundangundangan yang mengatur pembatasan tersebut adalah Pasal 153, huruf f Undang-Undang No. 13 Tahun 2003 tentang Ketenagakerjaan. Pasal tersebut mengizinkan Pemutusan Hubungan Kerja dengan alasan adanya ikatan perkawinan antara sesama pekerja, sepanjang itu telah diatur dalam perjanjian kerja, peraturan perusahaan, atau perjanjian kerja bersama.

Pengaturan tersebut artinya apabila antara pekerja melangsungkan pekawinan, maka salah satu dari mereka harus mundur dari perusahaan atau bahkan mendapat PHK berdasarkan perjanjian kerja, peraturan perusahaan, atau perjanjian kerja bersama. Hal ini tidak secara eksplisit dinyatakan sebagai larangan kawin, namun perusahaan dalam hal ini secara halus menghimbau pekerjanya untuk

${ }^{5}$ Arso Sastroatmojo, Hukum Perkawinan, Bulan Bintang, Jakarta, 2008, hal. 2.

${ }^{6}$ Achmad Ichsan, Hukum Perkawinan Bagi Yang Beragama Islam, Pradnya Paramita, Jakarta, 2006, hal. 7. 
Media Komunikasi dan Informasi Hukum dan Masyarakat

tidak bekerja satu atap dengan pasangan suami/istrinya. ${ }^{7}$

Salah satu kasus yang terjadi pada pasangan suami-istri yang bekerja pada perusahaan yang sama adalah pasangan yang bekerja di salah satu Badan Usaha Milik Negara (BUMN) yaitu PT. Perusahaan Listrik Negara (PLN) (Persero). Putri Lisma Untari, 25 tahun, pegawai PT PLN Pembangkit Sumatera Bagian Selatan Sektor Pembangkit Ombilin yang menikah dengan sesama pegawai PT. PLN. Alasan melangsungkan pernikahan karena padawaktu itu peraturan perusahaan tentang larangan menikah sesama pegawaimasih terjadi pro-kontra antara pihak perusahaan dengan Serikat Pekerja danjuga pada waktu itu sudah ada juga sesama pegawai yang menikah tetapi tidak dipermasalahkan oleh pihak perusahaan.

Ternyata keputusan Putri Lisma Untari untuk menikah merupakan keputusan yang dianggap salah oleh pihak perusahaan. Pada April 2012 Putri Lisma Untari dipanggil oleh pihak manajemen PT PLN (Persero) Pembangkit Sumatera Bagian Selatan dan meminta kepada Putri Lisma Untari untuk mengundurkan diri. SelanjutnyaPutri Lisma Untari menyampaikan masalah tersebut kepada Serikat Pekerja PTPLN (Persero), hasil perundingan antara Putri Lisma Untari dengan Serikat Pekerja adalah Putri Lisma Untari menolak melakukan pengunduran diri sebagaimana perintah dari manajemen PT PLN (Persero) yang bersangkutan.

Bulan Mei 2012 Putri Lisma Untari terkejut mengetahui bahwa tidak menerima gaji lagi, kemudian baru diketahui bahwa perusahaan telah melakukan Pemutusan

${ }^{7}$ Wurianalya Maria Novenanty, Pembatasan Hak Untuk Menikah Antara Pekerja Dalam Satu Perusahaan, http://journal.unpar.ac.id, diakses Sabtu 15 Juni 2019 Pukul $21.00 \mathrm{Wib}$.
Hubungan Kerja (PHK) terhadap dirinya secara sepihak. Karena sebelumnya dia tidak menerima surat PHK dari pihak perusahaan. Pada saat di PHK, Tari sedang mengandung 6 bulan. Putri Lisma Untari melakukan upaya musyawarah dengan PLN tetapi gagal, selain itu Putri Lisma Untari juga sudah mengupayakan mediasi dengan dinas tenaga kerja dan Komnas HAM, tapi hasilnya tidak mencapai kesepakatan. Padahal, dinas tenaga kerja menyarankan agar PLN mempekerjakan kembali Putri Lisma Untari. Karena tidak ada respon positif dari pihak perusahaan, Putri Lisma Untari menggugat PT PLN (Persero) Pembangkit Sumatera Bagian Selatan yang beralamat di Palembang ke Pengadilan Hubungan Industrial (PHI) Padang.

Namun terdapat suatu Keputusan Direksi No.025.K/DIR/2011 tertanggal 21 Januari 2011 tentang pernikahan antar pegawai yang berisi larangan menikah sesama pegawai, dimana dalam hal terjadi perkawinan antar pegawai, masing-masing pegawai melaporkan perkawinan tersebut ke perseroan dengan menyerahkan fotokopi akta perkawinan disertai dengan surat pengunduran diri salah satu pegawai dari perseroan, paling lambat 1 (satu) bulan kalender setelah tanggal perkawinan. Apabila Putri Lisma Untari tidak menyertakan surat permohonan pengunduran diri, maka salah satu pegawai dari pasangan suami isteri baik Putri Lisma Untari ataupun suaminya tersebut dianggap mengundurkan diri. Pada tanggal 26 April 2012, Kepala Divisi Pengembangan Sistem SDM melalui surat No. 1638/002/DIVSDM/2012 perihal Penjelasan Keputusan Direksi PT PLN (Persero) Nomor 025.K/DIR/2011, menyatakan bahwa Keputusan Direksi PT PLN (Persero) Nomor 025.K/DIR/2011 telah sesuai dengan Perjanjian 
Media Komunikasi dan Informasi Hukum dan Masyarakat

Kerja Bersama (PKB) dan tidak bertentangan dengan Undang-Undang Nomor 13 Tahun $2003 .{ }^{8}$

Mahkamah Konstitusi dalam rangka menegakkan konstitusi adanya larangan perkawinan dalam satu perusahaan, telah melaksanan pengujian konstitusional dalam Putusan MK No. 13/PUU-XV/2017 terhadap Pasal 153 ayat (1) huruf $f$ Undang-Undang Nomor 13 Tahun 2003 tentang Ketenagakerjaan yang mengabulkan pembatalan frasa, "kecuali telah diatur dalam perjanjian kerja, peraturan perusahaan, atau perjanjian kerja bersama" karena bertentangan dengan Pasal 28 ayat (2) UUD 1945 yang berbunyi "Setiap orang berhak untuk bekerja serta mendapat imbalan dan perlakuan yang adil dan layak dalam hubungan kerja" dan Pasal 28 B ayat (1) UUD 1945 yang menyebutkan setiap orang berhak membentuk keluarga dan melanjutkan keturunan melalui perkawinan yang sah." Putusan ini dianggap sebagai pelaksanaan fungsi Mahkamah Konstitusi sebagai penjamin hak-hak konstitusional warga negara".

Adanya respon ini, menunjukan sangat potensial terjadi permasalahan dalam penegakan Putusan No. 13/PUU-XV/2017.

\section{B. Rumusan Masalah}

Rumusan masalah dalam penelitian ini adalah:

1. Apakah faktor-faktor yang menyebabkan adanya larangan perkawinan sesama buruh atau pekerja pada satu perusahaan?

2. Bagaimanakah analisis pertimbangan hukum hakim dalam putusan Nomor 13/PUU-XV/2017?

${ }^{8}$ Raja Adil Siregar, Halalkan Nikah Sekantor MK Selamatkan 4 Pegawai PLN dari PHK, https://news.detik.com, diakses Sabtu 15 Juni 2019 Pukul $21.00 \mathrm{Wib}$.
3. Bagaimana dampak adanya putusan Mahkamah Konstitusi terhadap pencantuman klausul larangan perkawinan yang dilakukan antar pekerja?

\section{Metode Penelitian}

Jenis penelitian hukum yang digunakan adalah yuridis normatif yaitu "suatu penelitian yang menempatkan norma sebagai obyek penelitian, baik norma hukum dalam peraturan perundang-undangan, norma hukum yang bersumber dari suatu undang-undang"9. Disebut juga penelitian hukum doktrinal yaitu "penelitian hukum yang menggunakan data sekunder. Penelitian hukum normatif dikenal sebagai penelitian hukum yang bersifat kualitatif". ${ }^{10}$

Penelitian ini bersifat deskriptif analisis yaitu penelitian yang menggambarkan, menelaah, menjelaskan serta menganalisa peraturan perundang-undangan yang berkaitan pada tujuan penelitian ini. ${ }^{11}$

Analisis data adalah suatu proses mengatur, mengurutkan, mengelompokkan, memberikan kode dan mengategorikannya hingga kemudian mengorganisasikan dalam suatu bentuk pengelolaan data untuk menemukan tema dan hipotesis kerja yang diangkat menjadi teori substantif dan untuk menemukan teori dari data tersebut maka menggunakan metode kualitatif adalah penelitian yang mengacu pada norma hukum yang terdapat dalam peraturan perundangundangan dan putusan pengadilan serta norma-

\footnotetext{
${ }^{9}$ Soerjono Soekanto dan Sri Mamudji, Op.Cit, hal. 70. ${ }^{10}$ Ronny Hanitijo Soemitro, Metodelogi Penelitian Hukum, Ghalia, Jakarta, 2008, hal. 10.

${ }^{11}$ Kontjaraningrat, Metode-Metode Penelitian Masyarakat, Gramedia, Jakarta, 1997, hal. 41.
} 
Media Komunikasi dan Informasi Hukum dan Masyarakat

norma yang hidup dan berkembang dalam masyarakat. ${ }^{12}$

Analisis bahan-bahan hukum dalam penelitian ini akan dilakukan secara kualitatif artinya menguraikan bahan-bahan hukum secara bermutu dengan bentuk kalimat yang teratur, runtun, logis, dan tidak tumpang tindih serta efektif, sehingga memudahkan interpretasi bahan-bahann hukum dan pemahaman hasil analisa. Komprehensif artinya dilakukan secara mendalam dan dari berbagai aspek sesuai dengan lingkup penelitian. Analisis bahan hukum dalam penelitian ini dilakukan dengan teknik deskriptif, kontruksi hukum dan argumentasi yang selanjutnya dilakukan penilaian berdasarkan pada alasan-alasan yang bersifat penalaran hukum, yaitu dengan mengemukakan doktrin dan asas-asas yang ada kaitannya dengan permasalahan.

Penarikan kesimpulan merupakan proses terakhir analisis data, hal ini dilakukan dengan cara menguji kebenaran data yang diperoleh di lapangan kemudian diverifikasi lebih lanjut, sehingga menghasilkan suatu kesimpulan penelitian yang komprehensif, valid, dan obyektif.

Mengingat penelitian ini bersifat deskriptif dan analisis data yang dipergunakan dalam penelitian ini adalah analisis kualitatif, maka penarikan kesimpulan dengan menggunakan metode induktif yaitu data yang dipergunakan untuk menganalisa data yang terkumpul dengan jalan menguraikan atau menginterprestasikan hal-hal yang bersifat umum pada kesimpulan yang bersifat khusus yang merupakan proses pendekatan yang berangkat dari kebenaran yang bersifat umum

${ }^{12}$ Zainuddin Ali, Metode Penelitian Hukum, Sinar Grafika, Jakarta, 2009, hal. 105. mengenai suatu fenomena (teori) kemudian menggeneralisasi kebenaran tersebut pada suatu peristiwa atau data tertentu yang mempunyai ciri yang sama dengan fenomena yang bersangkutan, dengan memakai kaidah logika tertentu.

\section{Hasil dan Penelitian}

\section{A. Faktor-Faktor Yang Menyebabkan Adanya Larangan Perkawinan Sesama Buruh Atau Pekerja Pada Satu Perusahaan}

Pekerja dalam menjalankan pekerjaannya di perusahaan tentu memiliki hak dan kewajiban. Menurut Suratman bahwa, yang dimaksud dengan hak disini adalah "sesuatu yang harus diberikan kepada seseorang sebagai akibat dari kedudukan atau status dari seseorang, sedangkan kewajiban adalah suatu prestasi baik berupa benda atau jasa yang harus dilakukan oleh seseorang karena kedudukan atau statusnya". ${ }^{13}$ Berdasarkan pada status dan kedudukan seseorang sebagai pekerja, tentu ia memiliki hak yang utama yakni berhak untuk mendapatkan upah, sedangkan kewajibannya adalah melaksanakan pekerjaan sesuai dengan yang telah disepakati.

Perkawinan merupakan Hak Asasi Manusia yang dilindungi di negara Indonesia di dalam Konstitusi yakni dalam Undang-Undang Dasar Negara Republik Indonesia Tahun 1945 pada bagian Bab $X A$ tentang Hak Asasi Manusia pada Pasal 28 B ayat (1). "Setiap orang melakukan perkawinan tentu didasarkan pada kebutuhan yang sifatnya kodrati untuk membentuk rumah tangga yang kekal dan abadi serta untuk melanjutkan garis keturunannya

${ }^{13}$ Suratman, Hukum Ketenagakerjaan Indonesia, Permata Puri Media, Jakarta, 2010, hal.43. 
Media Komunikasi dan Informasi Hukum dan Masyarakat

dengan menciptakan generasi penerus dalam keluarga tersebut".

Perusahaan membuat larangan tersebut tidak semata-mata didasarkan karena rasa tidak suka terhadap pekerjanya yang ingin melangsungkan perkawinan. Perusahaan memiliki pandangan tersendiri yang menyebabkan munculnya aturan yang melarang bagi sesama pekerja yang memiliki ikatan perkawinan dalam perusahaannya. Aturan mengenai larangan adanya ikatan perkawinan dalam satu perusahaan bukan tanpa alasan.

Berdasarkan pada pandangan tersebut, maksud dari adanya larangan perkawinan antara sesama pekerja dalam satu perusahaan memiliki tujuan untuk mencegah hal-hal negatif di lingkungan perusahaan seperti sikap tidak profesional dalam bekerja serta mencegah adanya konflik pribadi atau konflik kepentingan dalam perusahaan.

Perusahaan sebagai kegiatan usaha yang didalamnya terdapat pekerja sebagai komponen penting yakni sebagai roda penggerak perusahaan, tentu pekerja dituntut untuk melakukan pekerjaannya secara profesional. Tuntutan tersebut yang menyebabkan pengusaha membuat peraturan yang melarang adanya ikatan perkawinan bagi sesama pekerjanya dalam perusahaan, sehingga dapat menjaga sikap profesional dari pekerja ketika melaksanakan pekerjannya. "Pertimbangan pengusaha yang menuntut pekerja agar dapat bersikap profesional dalam melaksanakan pekerjaan tersebut tentu demi menjaga eksistensi perusahaan dalam dunia persaingan bisnis".

Eksistensi pekerja dalam perusahaan apabila pekerja bersikap tidak profesional dalam melakukan pekerjaannya, tentu akan berpengaruh terhadap kegiatan beroperasinya perusahaan. Apabila perusahaan terganggu kegiatan beroperasinya yang disebabkankan dengan adanya sikap tidak profesional dari pekerja dalam melaksanakan pekerjaannya, dapat mengakibatkan perusahaan mengalami kerugian bahkan kemungkinan terburuknya perusahaan tersebut mengalami kebangkrutan. Berdasarkan hal tersebut, tentu dapat terlihat bahwa perusahaan dalam menerapkan peraturan yang melarang adanya ikatan perkawinan terhadap sesama pekerja di dalam perusahaannya, memiliki maksud tertentu yakni demi kemajuan perusahaan dengan menjaga sikap profesional pekerja dalam bekerja sehingga perusahaan melarang adanya perkawinan sesama pekerja dalam perusahaan tersebut.

Sebab lainnya yang menjadi dasar tindakan pengusaha yang melarang adanya ikatan perkawinan antara sesama pekerja dalam perusahaannya adalah mengacu kepada Undang-undang Republik Indonesia Nomor 13 Tahun 2003 tentang Ketenagakerjaan. Hal ini dapat terlihat pada Pasal 153 ayat (1) UndangUndang Nomor 13 Tahun 2003 tentang Ketenagakerjaan, pada huruf $f$ yang menyatakan bahwa "pekerja/buruh mempunyai pertalian darah dan atau ikatan perkawinan dengan pekerja/buruh lainnya di dalam satu perusahaan, kecuali telah diatur dalam perjanjian kerja, peraturan perusahan, atau perjanjian kerja bersama." Berdasarkan pada ketentuan asal tersebut digunakan sebagai sebab bagi pengusaha dalam membentuk larangan adanya ikatan perkawinan bagi sesama pekerja dalam perusahaannya. 
Media Komunikasi dan Informasi Hukum dan Masyarakat

\section{B. Analisis Pertimbangan Hukum Hakim}

Dalam Putusan Nomor 13/PUU$\mathrm{XV} / 2017$

Objek permohonan pengujian materiil adalah Pasal 153 ayat (1) huruf $f$ UndangUndang Nomor 13 Tahun 2003 tentang Ketenagakerjaan. Penjelasan Pemohon mengenai kewenangan Mahkamah Konstitusi untuk menguji Undang-Undang adalah:

a. Pasal 24 C ayat (1) Undang-Undang Dasar Negara Republik Indonesia Tahun 1945 menyebutkan bahwa salah satu kewenangan Mahkamah Konstitusi adalah melakukan pengujian Undang-Undang terhadap UUD 1945;

b. Pasal 10 ayat (1) huruf a Undang-Undang Nomor 8 Tahun 2011 tentang Perubahan Atas Undang-Undang Nomor 24 Tahun 2003 tentang Mahkamah Konstitusi menyatakan bahwa: "Mahkamah Konstitusi berwenang mengadili pada tingkat pertama dan terakhir yang putusannya bersifat final untuk menguji undang-undang terhadap Undang-Undang Dasar Negara Republik Indonesia Tahun 1945";

c. Berdasarkan Pasal 12 ayat (1) huruf a Undang-Undang Nomor 4 Tahun 2004 tentang Kekuasaan Kehakiman menyatakan: "Mahkamah Konstitusi berwenang mengadili pada tingkat pertama dan terakhir yang putusannya bersifat final untuk menguji Undang-Undang terhadap Undang-Undang Dasar Republik Indonesia Tahun 1945";

d. Bahwa objek permohonan adalah pengujian materiil Pasal 153 ayat (1) huruf $f$ UndangUndang No. 13 Tahun 2003 tentang Ketenagakerjaan oleh karena itu Mahkamah berwenang untuk melakukan pengujian undang-undang.
Berdasarkan Pasal 24C ayat Undang-undang Dasar Negara Republik Indonesia Tahun 1945, Pasal 10 ayat (1) huruf a Undang-UndangNomor 24 Tahun 2003 tentang Mahkamah Konstitusi sebagaimana telah diubah dengan Undang-undang Nomor 8 Tahun 2011 tentang Perubahan Atas Undang-undang Nomor 24 Tahun 2003 tentang Mahkamah Konstitusi, dan Pasal 29 ayat (1) huruf a Undang-undang Nomor 48 Tahun 2009 tentang Kekuasaan Kehakiman, salah satu kewenangan konstitusional Mahkamah Konstitusi adalah mengadili pada tingkat pertama dan terakhir yang putusannya bersifat final untuk menguji Undang-undang terhadap Undang-Undang Dasar 1945.

Amar putusan Putusan Mahkamah Konstitusi Nomor 13/PUU-XV/2017 sebagai berikut:

a. Mengabulkan permohonan para Pemohon untuk seluruhnya;

b. Menyatakan frasa "kecuali telah diatur dalam perjanjian kerja, peraturan perusahaan, atau perjanjian kerja bersama" dalam Pasal 153 ayat (1) huruf $f$ UndangUndang Nomor 13 Tahun 2003 tentang Ketenagakerjaan bertentangan dengan Undang-Undang Dasar Negara Republik Indonesia Tahun 1945 dan tidak mempunyai kekuatan hukum mengikat;

c. Memerintahkan pemuatan putusan ini dalam Berita Negara Republik Indonesia sebagaimana mestinya.

Berdasarkan pertimbangan hukum hakim Mahkamah Konstitusi Nomor 13/PUUXV/2017 terlihat bahwa Mahkamah Konstitusi mempertegas larangan pemutusan hubungan kerja (PHK) karena alasan menikah sesama pekerja dan memiliki hubungan darah dalam 
Media Komunikasi dan Informasi Hukum dan Masyarakat

satu perusahaan. Salah satu putusan Mahkamah Konstitusi yang menunjukan penjaminan hak asasi manusia yang dilindungi konstitusi yaitu putusan No. 13/PUU-XV/2017 mengenai larangan menikah bagi Pekerja/Buruh dalam satu kantor. Amar putusan ini, menyatakan frasa "kecuali telah diatur dalam perjanjian kerja, peraturan perusahaan, atau perjanjian kerja bersama" dalam Pasal 153 ayat (1) huruf $f$ UU No. 13 Tahun 2003 tentang Ketenagakerjaan bertentangan dengan UndangUndang Dasar Negara Republik Indonesia Tahun 1945 dan tidak mempunyai kekuatan hukum mengikat.

Menurut penulis, bahwa putusan Mahkamah Konstitusi sebagai yang bersifat final and binding berpengaruh terhadap akibat hukumnya dari putusannya. Putusan Mahkamah Konstitusi menjadi hukum dengan meniadakan keadaan hukum berdasarkan pembatalan norma dalam undang-undang, sekaligus menciptakan keadaan hukum baru. Mahkamah Konstitusi dalam putusan No.13/PUU-XV/2017 telah meniadakan hukum yang memberikan ruang kepada pengusaha untuk membuat larangan menikah terhadap pekerja/buruh dalam satu kantor sebagaimana yang diatur Pasal Pasal 153 ayat (1) huruf $f$ UU No. 13 tahun 2003 tentang Ketenagakerjaan, sekaligus menciptakan keadaan hukum baru yang memperbolehkan pekerja/buruh menikah dengan rekan sejawatnya dalam satu kantor.

Putusan Mahkamah Konstitusi yang meniadakan norma pelarangan menikah bagi pekerja/buruh pada satu kantor dalam perjanjian kerja, peraturan perusahaan, atau perjanjian kerja bersama, menurut penulis dapat dimaknai putusan tersebut memiliki kekuatan hukum yang setara dengan undang-undang. Berarti ketika perjanjian kerja, peraturan perusahaan, atau perjanjian kerja bersama, yang masih mengatur atau mengatur kembali larangan pernikahan pekerja/buruh dalam satu kantor, maka berdasarkan Pasal 52 ayat (1) UU No. 13 Tahun 2003 tentang Ketenagakerjaan yang berbunyi perjanjian kerja dibuat atas dasar pekerjaan yang diperjanjikan tidak bertentangan dengan ketertiban umum, kesusilaan, dan peraturan perundang-undangan yang berlaku seharusnya perjanjian kerja, peraturan perusahaan, atau perjanjian kerja bersama tersebut dapat dibatalkan karena telah kehilangan legitimasi hukum yang lebih tinggi.

Terjadinya pengabaian terhadap pelaksanaan putusan No. 13/PUU-XV/2017 cenderung disebabkan karena faktor ekonomi dan keuangan. Hal ini tercermin melalui pandangan Asosiasi Pengusaha Indonesia (APINDO) sebagai representasi pengusaha yang keberatan terhadap putusan karena akan terjadinya konflik kepentingan berpotensi mengganggu tata kelola perusahaan yang berdampak pada kondisi finansial dari kegiatan usaha, sehingga pengusaha lebih memilih untuk mencegah terjadinya hal tersebut dengan melarang adanya hubungan pernikahan diantara pekerja.

Menurut penulis akibat hukum dari putusan Mahkamah Konstitusi No. 13/PUU$\mathrm{XV} / 2017$ dalam sistem hukum Indonesia yaitu diperbolehkannya pekerja/buruh memiliki pasangan pernikahan dalam satu kantor atau dapat juga dikatakan bahwa pengusaha dilarang membuat perjanjian kerja yang melarang pekerja/pegawai memiliki hubungan pernikahan dalam satu kantor. Dengan demikian perjanjian kerja yang dilakukan oleh pekerja dengan perusahaan atau suatu instansi dalam hal ini 
Media Komunikasi dan Informasi Hukum dan Masyarakat

merupakan objek penting untuk memberikan keadilan bagi para pencari keadilan.

Berdasarkan putusan Mahkamah Konstitusi No. 13/PUU-XV/2017, maka pengusaha dilarang melakukan pemutusan hubungan kerja dengan alasan pekerja atau buruh mempunyai pertalian darah dan atau ikatan perkawinan dengan pekerja atau buruh lainnya di dalam satu perusahaan. Artinya, setelah putusan Mahkamah Konstitusi ini diucapkan sesama pekerja boleh menikah dalam satu perusahaan tanpa pemutusan hubungan kerja termasuk memiliki hubungan darah. Perusahaan tidak boleh melakukan pemutusan hubungan kerja dengan dalih diatur dalam perjanjian kerja, peraturan perusahaan atau perjanjian kerja bersama, memutuskan hubungan kerja dengan pekerjanya karena alasan menikah atau memiliki hubungan darah dalam satu perusahaan.

Berdasarkan pertimbangan hukum Mahkamah Konstitusi bahwa perkawinan adalah takdir yang tidak dapat direncanakan sehingga menjadikan sesuatu yang bersifat takdir sebagai syarat untuk mengesampingkan pemenuhan hak asasi manusia, dalam hal ini hak ataspekerjaan serta untuk membentuk keluarga adalah tidak dapat diterima sebagai alasan yang sah secara konstitusional.

Mengacu Putusan Mahkamah Konstitusi Nomor13/PUUXV/2017 bahwa perusahaan dilarang memutusan hubungan kerja karyawan karena alasanpekerja/buruh mempunyai ikatan perkawinan dengan pekerja atau buruh lainnya didalam satu perusahaan/kantor. Pernyataan yang tertuang dalam Pasal 5 UndangundangNomor 13Tahun 2003 tentang Ketenagakerjaan bahwa "Setiap tenaga kerja memilikikesempatan yang sama tanpa diskriminasi untuk memperoleh pekerjaan", sejalan dengan Pasal 28 D ayat 2 UUD 1945 yang menjelaskan bahwa setiap orang berhak atas pekerjaan dan penghidupan yang layak.

Apabila dalam suatu perusahaan yang mempersyaratkan pekerja/buruh tidak boleh memiliki ikatan perkawinan dengan pekerja/buruh lainnya didalam satu perusahaan/kantor dan menjadikan hal itu sebagai dasar dapat dilakukannya pemutusan hubungan kerja terhadap pekerja/buruh yang bersangkutan maka hal tersebut batal demi hukum, karena sesuai Putusan Mahkamah Konstitusi Nomor 13/PUU-XV/2017 telah memperbolehkan adanya ikatan perkawinan dengan pekerja/buruh lainnya di dalam satu perusahaan/kantor.

\section{Dampak Adanya Putusan Mahkamah Konstitusi Terhadap Pencantuman Klausul Larang Perkawinan Antar Pekerja}

Berdasarkan pada sebab-sebab terjadinya larangan ikatan perkawinan antara sesama pekerja dalam satu perusahaan baik dalam perspektif pandangan pengusaha maupun Undang-Undang Ketenagakerjaan sebagai sebab, hal tersebut yang mengakibatkan pengusaha membentuk peraturan berupa larangan ikatan perkawinan terhadap sesama pekerja dalam perusahaannya. Peraturan tersebut kemudian diaplikasikan oleh pengusaha dalam perjanjian kerja, peraturan perusahaan, maupun perjanjian kerja bersama.

Larangan perkawinan antara sesama pekerja dalam sebuah perusahaan sebelum adanya Putusan Mahkamah Konstitusi Nomor 13/PUU-XV/2017, pengusaha membentuk larangan tersebut mendasarkan pada Pasal 153 
Media Komunikasi dan Informasi Hukum dan Masyarakat

ayat (1) huruf $f$ Undang Undang Nomor 13 Tahun 2003 tentang Ketenagakerjaan.

"Pembentukan larangan tersebut tidak hanya semata-mata mendasarkan pada ketentuan pasal tersebut, melainkan ada sebab-sebab sebagaimana pandangan dari pengusaha yang menyebabkan pembentukan larangan perkawinan antara sesama pekerja dalam perusahaannya.

Pengaturan mengenai larangan tersebut sebagaimana dalam ketentuan Pasal 153 ayat (1) huruf $f$ Undang Undang Nomor 13 Tahun 2003 tentang Ketenagakerjaan sebelum dinyatakan tidak memiliki kekuatan hukum mengikat dalam Putusan Mahkamah Konstitusi Nomor 13/PUU-XV/2017, pengaturan larangan adanya ikatan perkawinan tersebut diaplikasikan dalam klausul perjanjian kerja, peraturan perusahaan, maupun perjanjian kerja bersama. Pada umumnya klausul larangan adanya ikatan perkawinan antar sesama pekerja tersebut dibentuk dalam perjanjian kerja, peraturan perusahaan, maupun perjanjian kerja bersama dengan disertai sanksi apabila dilanggar yakni berupa sanksi pemutusan hubungan kerja.

Larangan yang dibentuk oleh pengusaha terkait adanya ikatan perkawinan terhadap sesama pekerja dalam perusahaannya yang kemudian diaplikasikan dalam perjanjian kerja, peraturan perusahaan, dan perjanjian kerja bersama dan disepakati antara pekerja dan pengusaha dalam membentuk hubungan kerja". Apabila ditinjau dalam perspektif hukum perjanjian, larangan yang dibentuk oleh pengusaha tersebut kemudian disepakati antara pekerja dan pengusaha sehingga antara pekerja dan pengusaha terdapat perjanjian yakni perjanjian untuk mematuhi dan melaksanakan segala hal termasuk larangan adanya ikatan perkawinan yang diatur dalam perjanjian kerja, peraturan perusahaan, maupun perjanjian kerja bersama.

Berkenaan dengan perjanjian antara pekerja dan pengusaha untuk mematuhi dan melaksanakan hal-hal dalam perjanjian kerja, peraturan perusahaan serta perjanjian kerja bersama, perlu ditinjau terlebih dahulu definisi perjanjian, sehingga pemahaman perjanjian dalam hubungan kerja tidak hanya sebatas pada perjanjian kerja saja. Pasal 1313 Kitab Undang-Undang Hukum Perdata yang menyatakan bahwa : "suatu perjanjian adalah suatu perbuatan dengan mana satu orang atau lebih mengikatkan dirinya terhadap satu orang lain atau lebih".

Berdasarkan pada Pasal 1313 Kitab Undang-Undang Hukum Perdata tersebut, kemudian R. Subekti memberikan definisi perjanjian adalah "suatu peristiwa di mana seorang berjanji kepada seorang lain atau di mana dua orang itu saling berjanji untuk melaksanakan sesuatu hal". ${ }^{14}$

Hubungan kerja yang terjalin antara pengusaha dan pekerja kadang terjadi ketidakseimbangan. Hal ini karena adanya pandangan pengusaha memiliki kedudukan yang lebih tinggi dibandingkan dengan kedudukan pekerja. Hal inilah yang kadang menjadi sebab pengusaha memaksakan kepada pekerja untuk menerima dan mematuhi aturan larangan sesama pekerja memiliki ikatan perkawinan dalam perusahaannya. Apabila dikaji sesungguhnya antara pengusaha dan pekerja memiliki kedudukan yang seimbang. Kedudukan yang seimbang tersebut terlihat

${ }^{14}$ Agus Yudha Hernoko, Hukum Perjanjian Azas Proporsionalitas dalam Kontrak Komersial, LaksBang Mediatama, Yogyakarta, 2008, hal. 14. 
Media Komunikasi dan Informasi Hukum dan Masyarakat

pada kedudukan pengusaha yang membutuhkan pekerja untuk melaksanakan pekerjaan dalam perusahaannya, sedangkan pekerja membutuhkan pekerjaan untuk mendapatkan upah. Hal ini berarti sesungguhnya kedudukan pengusaha dan pekerja seimbang karena antara pengusaha dan pekerja saling membutuhkan. "Pengusaha dan pekerja yang ingin melakukan penyesuaian kehendak haruslah kesepakatan tersebut haruslah seimbang antara kedua belah pihak tanpa adanya paksaan atau intervensi, termasuk pula dalam hal menyepakati aturan larangan bagi sesama pekerja untuk memiliki ikatan perkawinan dalam perusahaannya".

Perjanjian yang terjalin antara pengusaha dan pekerja yang tentunya sepakat untuk mematuhi isi dari perjanjian kerja, peraturan perusahaan, maupun perjanjian kerja bersama, haruslah dilandaskan pada asas-asas hukum perjanjian. "Apabila melihat pada asasasas hukum perjanjian, terdapat beberapa asas yang dapat menjadi landasan seperti berupa asas kebebasan berkontrak, asas pacta sunt servanda, asas itikad baik, maupun asas konsensualisme".

Berkenaan dengan adanya aturan larangan ikatan perkawinan antara sesama pekerja dalam perusahaan yang dibentuk oleh pengusaha dalam perjanjian kerja, peraturan perusahaan, maupun perjanjian kerja bersama, aturan tersebut dibentuk dengan dilandasi pada kebebasan berkontrak. Pasca adanya Putusan Mahkamah Konstitusi Nomor 13/PUU-XV/2017 yang menyatakan bahwa frasa "kecuali telah diatur dalam perjanjian kerja, peraturan perusahaan, atau perjanjian kerja bersama" telah dinyatakan bertentangan dengan UndangUndang Dasar Negara Republik Indonesia
Tahun 1945 dan tidak mempunyai kekuatan hukum mengikat. "Pengusaha jika masih membentuk aturan larangan adanya ikatan perkawinan antara sesama pekerja tidak bisa dilandaskan pada asas kebebasan berkontrak karena hal ini bertentangan dengan UndangUndang dan Undang-Undang Dasar Negara Republik Indonesia Tahun 1945".

Sebelum Putusan Mahkamah Konstitusi tersebut diputus, Pasal 6 ayat (1) bertentangan, dan tidak harmonis dengan Pasal 153 ayat (1) huruf $f$ UU Ketenagakerjaan, serta melanggar kebebasan pekerja untuk dapat tetap bekerja di perusahaan yang sama dengan calon istri/suami yang juga bekerja di perusahaan tersebut, pekerja tersebut hanya memiliki 2 (dua) pilihan, yakni: tetap bekerja di perusahaan tersebut namun tidak menjadi menikah dengan calon tersebut atau salah satu dari pekerja tersebut mengundurkan diri dari perusahaan tersebut dan tetap menjadi nikah. "Setelah permohonan pemohon diputus Mahkamah Konstitusi, pasangan yang ingin menikah tidak perlu ragu, dan penantian mereka menunggu Putusan Mahkamah Konstitusi tersebut telah terjawab, pasangan tersebut dapat tetap melangsungkan perkawinan, dan bekerja di satu perusahaan yang sama".

Mahkamah Konstitusi yang mengabulkan perlindungan hak konstitusional pekerja yang melaksanakan pernikahan sesama pekerja dalam satu atap perusahaan. Sebelum terbit putusan Putusan Nomor 13/PUU-XV/2017, banyak pekerja kehilangan pekerjaan, merasa dirugikan, dan diskriminasi hak konstitutionalnya, sebagaimana diakomodir dalam Pasal 27 dan Pasal 28 UUD 1945. Setelah Pasal 153 ayat (1) Undang Undang Nomor 13 Tahun 2003 tentang Ketenagakerjaan 
Media Komunikasi dan Informasi Hukum dan Masyarakat

dibatalkan oleh Mahkamah Konstitusi, patut dianalisis bagaimana dampak putusan tersebut bagi undang-undang ketenagakerjaan di Indonesia serta konsekuensi hukumnya terhadap peraturan internal perusahaan.

"Setelah putusan Mahkamah Konstitusi dimuat dalam Berita Negara Republik Indonesia, idealnya perusahaan-perusahaan di Indonesia harus melakukan penyesuaian terhadap ketentuan internal perusahaannya untuk mencegah timbulnya gugatan dari pihak-pihak terkait".

"Putusan Mahkamah Konstitusi sejak diucapkan di hadapan sidang yang terbuka untuk umum dapat mempunyai 3 (tiga) kekuatan, yaitu kekuatan mengikat, kekuatan pembuktian, dan kekuatan eksekutorial"15. Pada perkara larangan perkawinan antar pekerja, para pemohon dalam permohonannya kepada Mahkamah Konstitusi mengemukakan bahwa hak konstitusionalnya telah dirugikan oleh berlakunya Pasal 153 ayat (1) huruf f Undang Undang Nomor 13 Tahun 2003 tentang Ketenagakerjaanberupa jaminan kerja dan penghidupan yang layak karena ketentuan tersebut dapat menyebabkan terjadinya pemutusan kerja. Dalam hal Perusahaan membuat Peraturan Perusahaan sesuai dengan Pasal 153 ayat (1) huruf $f$ Undang Undang Nomor 13 Tahun 2003 tentang Ketenagakerjaan, maka Perusahaan akan menghilangkan jaminan kerja Para Pekerja yang akan melakukan Perkawinan sesama Pekerja dalam satu perusahaan dan juga menghilangkan hak atas penghidupan yang layak serta mendapat imbalan dan perlakuan yang adil dalam hubungan keja yang dijamin

\footnotetext{
${ }^{15}$ Rian Van Frits Kapitan, Kekuatan Mengikat Putusan Constitutional Review Mahkamah Konstitusi Terhadap Mahkamah Agung, Jurnal MMH, Jilid 44 No. 4, Oktober 2015, hal. 5.
}

oleh Pasal 28D ayat (1) UUD 1945 yang berbunyi: "Setiap orang berhak atas pengakuan, jaminan, perlindungan, dan kepastian hukum yang adil serta perlakuan yang sama dihadapan hukum."

Sudah menjadi kewajiban bagi setiap perusahaan untuk berpedoman pada Undang Undang Nomor 13 Tahun 2003 tentang Ketenagakerjaan yang mengatur bahwa perusahaan yang mempekerjakan sekurangkurangnya 10 (sepuluh) orang, pengusaha wajib membuat peraturan perusahaan kecuali perusahaan telah mempunyai perjanjian kerja bersama (Pasal 108 Undang Undang Nomor 13 Tahun 2003 tentang Ketenagakerjaan). "Persamaan peraturan perusahaan dengan perjanjian kerja bersama adalah sama-sama memuat tentang syarat-syarat kerja, hak dan kewajiban para pihak serta tata tertib perusahaan". Perbedaannya adalah :

Putusan Mahkamah Konstitusi Nomor 13/PUU-XV/2017 perihal pengujian UndangUndang Nomor 13 Tahun 2003 tentang Ketenagakerjaan terhadap UUD NRI 1945, khususnya pada Pasal 153 ayat (1) huruf $f$ yang diuji dengan Pasal 28B ayat (1) UUD NRI 1945 "memberikan harapan baru terhadap jaminan pemenuhan hak asasi manusia, khususnya terkait hak untuk menikah dan membentuk keluarga melalui perkawinan yang sah". ${ }^{16}$

Putusan tersebut menyatakan bahwa frasa "kecuali telah diatur dalam perjanjian kerja, peraturan perusahaan, atau perjanjian kerja bersama" pada Pasal 153 ayat (1) huruf $f$ Undang-Undang Ketenagakerjaan bertentangan

${ }^{16}$ Ayunita Nur Rohanawati, Kesetaraan Dalam Perjanjian Kerja Dan Ambiguitas Pertimbangan Hukum Mahkamah Konstitusi, Kajian Putusan Mahkamah Konstitusi Nomor 13/PUU-XV/2017Jurnal Yudisial Vol. 11 No. 3 Desember 2018, hal, 268. 
Media Komunikasi dan Informasi Hukum dan Masyarakat

dengan UUD NRI 1945 dan tidak mempunyai kekuatan hukum mengikat. Putusan tersebut meneguhkan pengaturan bahwa pengusaha dilarang melakukan pemutusan hubungan kerja dengan alasan pekerja/buruh mempunyai pertalian darah dan/atau ikatan perkawinan dengan pekerja/buruh lainnya di dalam satu perusahaan.

\section{Mahkamah Konstitusi yang} mengabulkan permohonan uji materi Pasal 153 Ayat 1 Huruf $f$ Undang-Undang Nomor 13 tahun 2003 tentang Ketenagakerjaan, maka dengan adanya putusan Mahkamah Konstitusi tersebut, sebuah perusahaan tidak bisa menetapkan aturan yang melarang karyawannya menikah dengan rekan kerja satu kantor. Mahkamah Konstitusi sudah membatalkan gugatan tersebut artinya tidak dilarang menikah atau bertalian darah dengan teman satu perusahaan.

Perusahaan yang melakukan Pemutusan Hubungan Kerja terhadap pekerja atau karyawannya atas alasan melakukan pernikahan sesama pekerja dalam suatu perusahaan harus mempekerjakan kembali pekerja atau karyawannya. Sesuai undangundang harus pekerjakan kembali, atau tetap membayar upah. Mahkamah Konstitusi dalam pertimbangannya menyatakan pertalian darah atau perkawinan adalah takdir, hal yang tak dapat dihindarkan. Selain itu, dengan adanya perkawinan, tidak ada hak orang lain yang terganggu. Mahkamah Konstitusi juga menyatakan, perusahaan mensyaratkan pekerja atau buruh tidak boleh mempunyai pertalian darah atau perkawinan dengan pekerja lain dalam satu perusahaan dan menjadikan hal itu sebagai "alasan pemutusan hubungan kerja tidak sejalan dengan norma Pasal 28 D Ayat (2) UUD 1945 serta Deklarasi Universal Hak Asasi
Manusia". ${ }^{17}$ Dengan demikian jelaslah bahwa pasca Putusan Nomor 13/PUU-XV/2017, maka hak untuk membangun keluarga dalam perkawinan yang sah telah dijamin pemenuhannya.

Adanya Putusan MK Nomor 13/PUU$\mathrm{XV} / 2017$ tersebut maka perjanjian kerja, peraturan perusahaan maupun perjanjian kerja bersama tidak boleh memuat larangan adanya perkawinan antar pekerja dalam satu perusahaan. Perjanjian kerja, peraturan perusahaan maupun perjanjian kerja bersama telah mengatur tentang ketentuan tersebut maka akan batal demi hukum dan dengan adanya Putusan MK Nomor 13/PUU-XV/2017 tersebut maka peraturan yang memuat adanya larangan tersebut tidak dapat digunakan kembali.

\section{Kesimpulan \& Saran}

A. Kesimpulan

Faktor-faktor menyebabkan adanya larangan perkawinan sesama buruh atau pekerja pada satu perusahaan adalah untuk menjaga sikap profesional dari pekerja ketika melaksanakan pekerjannya demi menjaga eksistensi perusahaan dalam dunia persaingan bisnis. Sebab lainnya yang menjadi dasar tindakan pengusaha yang melarang adanya ikatan perkawinan antara sesama pekerja dalam perusahaannya adalah pekerja atau buruh mempunyai pertalian darah dan atau ikatan perkawinan dengan pekerja atau buruh lainnya di dalam satu perusahaan kecuali telah diatur dalam perjanjian kerja, peraturan perusahan, atau perjanjian kerja bersama dan hal ini menjadi bagi perusahaan membuat perjanjian

\footnotetext{
17 Nabilla Tashandra, Pasca Putusan MK Soal Nikah Antar Karyawan Se-Kantor Perusahaan, https://nasional.kompas.com, diakses Senin 30 September 2019.
} 
Media Komunikasi dan Informasi Hukum dan Masyarakat

kerja yang melarang sesama karyawan menikah.

Analisis pertimbangan hukum hakim dalam putusan Nomor 13/PUU-XV/2017 adalah jelas bahwa Pasal 153 ayat (1) huruf $f$ Undang Undang Ketenagakerjaan tidak berlaku lagi, karena frasa kecuali telah diatur dalam perjanjian kerja, peraturan perusahaan, atau perjanjian kerja bersama bertentangan dengan UUD Tahun 1945 dan tidak mempunyai kekuatan hukum mengikat. Putusan tersebut juga mempunyai konsekuensi memberikan perlindungan hak konstitusional terhadap warga negara secara optimal, tertutama dalam hak untuk berkeluarga dan hak untuk melanjutkan keturunan melalui perkawinan yang sah.

Dampak adanya putusan Mahkamah Konstitusi terhadap pencantuman klausul larangan perkawinan adalah pengusaha tidak dapat mencantumkan alasan adanya PHK terhadap pekerja yang memiliki ikatan perkawinan dengan pekerja lain pada satu kantor yang sama dalam perjanjian kerja, peraturan perusahaan maupun perjanjian kerja bersama, sehingga apabila pengusaha mencantumkan hal tersebut maka dianggap melanggar putusan Putusan Mahkamah Konstitusi No 13/PUU-XV/2017.

\section{B. Saran}

Berdasarkan penelitian yang telah dilakukan terhadap Putusan Mahkamah Konstitusi No. 13/PUU-XV/2017 yang menghapuskan larangan menikah antara pekerja di dalam satu perusahaan maka peneliti memberikan saran sebagai berikut :

1. Agar setiap perusahaan baik Badan Usaha Milik Negara maupun perusahan milik swasta di dalam membuat suatu peraturan yang berkaitan dengan pernikahan, harus berdasarkan ketentuan yang berlaku pada saat ini.

2. Undang-Undang Republik Indonesia Nomor 13 Tahun 2003 tentang Ketenagakerjaan semestinya dibentuk dengan memperhatikan Hak Asasi Manusia dari pekerja maupun pengusaha, sehingga apabila terjadi revisi terhadap UndangUndang ini diharapkan nantinya akan lebih dapat memberikan perlindungan hukum dalam segi Hak Asasi Manusia terutama bagi pihak pekerja sehingga dapat mencegah terjadinya pelanggaran Hak Asasi Manusia di dalam hubungan kerja yang tercipta antara pekerja dan pengusaha.

3. Mengingat bahwa Putusan Mahkamah Konstitusi No 13/PUU-XV/2017 merupakan putusan baru, maka harus ada sosialisasi untuk masyarakat terutama bagi kalangan pengusaha terkait dengan Putusan Mahkamah Konstitusi No 13/PUU-XV/2017. Terutama bagi pekerja yang tidak mengetahui adanya aturan tersebut

\section{DAFTAR PUSTAKA}

\section{A. Buku}

Ali, Zainuddin. 2009. Metode Penelitian Hukum, Sinar Grafika, Jakarta.

Hernoko, Agus Yudha, 2008. Hukum Perjanjian Azas Proporsionalitas dalam Kontrak Komersial, LaksBang Mediatama, Yogyakarta, 2008

Ichsan, Achmad, 2006. Hukum Perkawinan Bagi Yang Beragama Islam, Pradnya Paramita, Jakarta, 2006.

Kontjaraningrat, 1997. Metode-Metode Penelitian Masyarakat, Gramedia, Jakarta, 1997. 
Media Komunikasi dan Informasi Hukum dan Masyarakat

Manan. Abdul, 2003. Aneka Masalah Hukum Materil Dalam Praktek Peradilan Agama, Pustaka Bangsa Press, Jakarta, 2003.

Mukhtar, Kamal, 2013. Asas-Asas Hukum Islam Tentang Perkawinan, Bulan Bintang, Jakarta, 2013.

Sastroatmojo, Arso, 2008. Hukum Perkawinan, Bulan Bintang, Jakarta, 2008.

Soekanto, Soerjono, 2006.Pengantar Penelitian Hukum, UI Pers, Jakarta, 2006.

Soemitro, Ronny Hanitijo, 2004. Metodologi Penelitian Hukum dan Jurimetri, Ghalia Indonesia, Jakarta, 2004.

Soemiyati, 2012. Hukum Perkawinan Dan Undang-Undang Perkawinan, Liberty, Yogyakarta, 2012.

Suratman, 2010. Hukum Ketenagakerjaan Indonesia, Permata Puri Media, Jakarta, 2010.

\section{B. Jurnal}

Kapitan, Rian Van Frits, Kekuatan Mengikat Putusan Constitutional Review Mahkamah Konstitusi Terhadap Mahkamah Agung, Jurnal MMH, Jilid 44 No. 4, Oktober 2015.

Novenanty, Wurianalya Maria, "Pembatasan Hak Untuk Menikah Antara Pekerja Dalam Satu Perusahaan," http://journal.unpar.ac.id, diakses Sabtu 15 Juni 2019 Pukul 21.00 Wib.

Rohanawati, Ayunita Nur, Kesetaraan Dalam Perjanjian Kerja Dan Ambiguitas Pertimbangan Hukum Mahkamah Konstitusi, Kajian Putusan Mahkamah Konstitusi Nomor 13/PUU-XV/2017Jurnal Yudisial Vol. 11 No. 3 Desember 2018.

\section{Internet}

Siregar, Raja Adil, "Halalkan Nikah Sekantor MK Selamatkan 4 Pegawai PLN dari PHK", https://news.detik.com, diakses Sabtu 15 Juni 2019 Pukul 21.00 Wib.

Tashandra, Nabilla, Pasca Putusan MK Soal Nikah Antar Karyawan Se Kantor Perusahaan", https://nasional.kompas.com, diakses Senin 30 September 2019

\section{Peraturan Perundang-Undangan}

UUD 1945 Hasil Amandemen dan ProsesAmandemen UUD 1945.

Undang-Undang Nomor 1 Tahun 1974 tentang Perkawinan .

Undang-Undang RI Nomor 13 Tahun 2003 Tentang Ketenagakerjaan, L.N.R.I. Tahun 2003.

Kompilasi Hukum Islam. 